\title{
Pola Penerapan Sistem 'ngabdi' yang Dilakukan Pondok Pesantren Bahrul Maghfiroh Malang dalam Konteks Manajemen Sumber Daya Manusia
}

\author{
Bambang Septiawan1, M.Adib Mawardi², Muhammad Rizal ${ }^{3}$ \\ 1,2,3FakultasEkonomi Unisba Blitar,Fakultas Ekonomi Unisba Blitar, danPondok Pesantren Bahrul Maghfiroh \\ email: 10kbamz@gmail.com,2adibunisba@gmail.com,3 gibranrizal1998@gmail.com
}

Kata kunci:

Pengembangan SDM

Ngabdi

Budaya Pesantren

Keywords:

Human Resource Development Serving

Islamic Boarding School Culture

Bambang Septiawan, M.Adib Mawardi, Muhammad Rizal (2020). Pola Penerapan Sistem 'ngabdi'yang Dilakuka Pondok Pesantren Bahrul MaghfirohMalang dalam Konteks Manajemen Sumber Daya Manusia. Akuntabilitas: Jurnal Ilmiah IlmuIlmu Ekonomi, 13(2), 1-13

\begin{abstract}
ABSTRAK
Penelitian ini bertujuan untuk menganalisa pola penerapan sistem 'ngabdi' yang diterapkan Pesantren Bahrul Mahfiroh dalam konteks MSDM. Penelitian ini sebearnya memfokuskan pada pengembangan sumber daya manusia yang ada pada pondok pesantren Bahrul Maghfiroh Malang. Hal ini sangat menarik karena ada integrasi antara budaya pesantren dan teori MSDM yang dilakukan dalam lingkup ekonomi dan bisnis. Selain itu, akulturasi teori pengembangan SDM dan budaya pesantren juga dibahas dalam penelitian ini. Mengabdi dilakukan pesantren salah satunya untuk meningkatkan kulaitas output santrinya. Metode yang digunakan menggunakan pendekatan kualitatif dan termasuk dalam ruang lingkup deskriptif karena menjabarkan tentang fenomena yang terjadi dalam penelitian ini. Model pendekatan Miles dan Huberman diadopsi untuk teknik analisa data yang dilakukan. Hasil membuktikan jika 'ngabdi' juga mengaplikasikan teori MSDM meskipun beberapa faktor diakulturasikan dengan kearifan pesantren itu sendiri. Secara umum pola penerapan pengabdian yang ada di Bahrul Maghfiroh menerapkan teori MSDM mulai dari perekrutan, pelatihan, kompensasi, dan pemutusan hubungan kerja, meski ada modifikasi yang sesuai dengan kebutuhan pesantren.
\end{abstract}

\section{ABSTRACT}

This study aims to analyze the pattern of implementing the 'ngabdi' system applied to the Bahrul Mahfiroh Islamic Boarding School in the context of HRM. This research is actually focused on the development of human resources in the Islamic boarding school Bahrul Maghfiroh Malang. This is very interesting because there is an integration between pesantren culture and HRM theory which is carried out in the economic and business spheres. In addition, acculturation of human resource development theory and Islamic boarding school culture is also discussed in this study. One of the ways to serve the pesantren is to increase the quality of the output of the students. The method used is a qualitative approach and is included in the descriptive scope because it describes the phenomena that occur in this study. The Miles and Huberman approach model is adopted for the data analysis technique performed. The results prove that 'ngabdi' also applies the HRM theory even though several factors are acculturated with the wisdom of the pesantren itself. In general, the implementation pattern of service in Bahrul Maghfiroh applies the HRM theory

Pola Penerapan Sistem ‘ngabdi'yang Dilakuka Pondok Pesantren Bahrul MaghfirohMalang dalam Konteks Manajemen Sumber Daya Manusia 


\section{PENDAHULUAN}

Pondok pesantren merupakan lembaga pendidikan dan juga organisasi yang ada dalam satuan masyarakat, di sini banyak dilakukan aktifitas mulai dari keagamaan sampai sosial dan ekonomi. Contohnya, mengaji rutinan bulanan, belajar ilmu tentang Islam, dan kegiatan kerja bakti bersama warga sekitar. Seiring dengan perkembangan zaman pondok pesantren juga banyak melakukan perubahan untuk terus memperbaiki sistem kinerja organisasi di dalamnya agar selalu relevan dengan masanya. Oleh karena itu dibutuhkan orang-orang yang berkualitas di dalamnya, yakni ustadz maupun pengurus yang ada di pondok pesantren tersebut.

Untuk mendapatkan sosok berkompeten tersebut pondok pesantren melakukan proses manajemen sumberdaya manusia yang berkualitas dan berkelanjutan untuk mencapai tujuan pesantren tersebut. Dessler (2013) menjelaskan jika manajemen sumberdaya manusia yang baik akan mampu mengangkat hasil yang positif pada organisasi. Sehingga, pada saat perekrutan santri merupakan elemen yang krusial bagi pondok pesantren, terutama untuk ustadz dan pengurus, karena mereka yang akan membawa ruh pondok pesantren agar lebih maju ke depannya. Selanjutnya, penempatan, pelatihan, sampai pengaturan habisnya masa bekerja juga merupakan faktor yang sangat berperan penting pada kemajuan sistem yang ada di sana.

Pondok pesantren Bahrul Maghfiroh Malang merupakan pondok yang masih menganut sistem tradisional dalam menjalankan sistem manajemen sumberdaya manusianya. Guru dan pengurus di dalamnya masih menggunakan model "ngabdi", yaitu suatu kerja suka rela dalam sebuah organisasi pondok pesantren dengan dasar keikhlasan sebagai wujud terimakasih atas ilmu yang diberikan selama belajar di pondok tersebut. Fahrurrozi (2015) menyatakan ngabdi adalah tinggal ditempat atau rumah Kiyai (termasuk pondok pesantren secara 
keseluruhan) untuk melayani, contoh memijat, mencuci pakaian, mengurus santri dan lain sebagainya.

Walupun demikian "ngabdi" sering kali mengakibatkan beberapa fenomena ketika berseberangan dengan semakin majunya zaman. Para guru maupun pengurus secara alamiah pasti akan berhasrat untuk memenuhi kebutuhannya. Namun di sini mereka tidak mengejar kompensasi yang besar, mereka hanya ingin "ngabdi" sebagai wujud terimakasihnya. Atsniah (2019) mengungkapkan santri mengabdi memiliki harapan serta tujuan untuk kehidupannya yaitu untuk mencari keberkahan dari Kiyainya. Sehingga, mereka dapat hidup lebih bermanfaat untuk orang lain nantinya.

Penelitian ini sangat penting dilakukan karena "ngabdi" merupakan sebuah proses manajemen sumberdaya manusia yang melibatkan perekrutan, pelatihan, penempatan, kompensasi dan masa berhenti atau habisnya masa pengabdian. Hal yang unik dari mengabdi adalah durasi waktu bekerja yang tidak pasti kadang ada yang beberapa tahun saja bahkan sampai bertahan dengan waktu yang lama. Dedikasi dari para murid yang mengabdi tentu juga jadi faktor unik berikutnya. Meskipun ukuran mereka bukan materi tapi mereka sangat ingin untuk menyumbangkan seluruh tenaganya dalam memajukan pesantren mereka.

Oleh sebab itu meneliti fenomena ini tentu saja menjadi hal baru yang menarik dalam dunia organisasi dan manajemen sumberdaya manusia, karena selama ini jika melihat pada teori sumberdaya manusia tentu sedikit banyak akan membawa perbedaan dan gejala untuk diidentifikasi lebih lanjut dan nantinya mampu memberikan sebuah pemahaman baru tentang dunia manajemen sumberdaya manusia. Hal tersebut banyak terjadi di kalangan pesantren terutama di Pondok Pesantren Bahrul Maghfiroh Malang. Pola penerapan sistem "ngabdi" yang salah dalam pengelolaan maka justru menimbulkan kerancuan dan ketidakefektifan dalam bekerja, namun jika dilakukan dengan tepat akan membawa banyak manfaat dan kemajuan bagi organisasi tersebut.

Pelaksanaan proses manajemen sumber daya manusia dalam pondok pesantren merupakan sesuatu hal yang menarik untuk diteliti. Secara teoritis 
pelaksanaan sistem MSDM di pondok pesantren tentunya memiliki kekhususan sendiri seperti proses pendidikan atau training yang lebih menekankan pada praktek dan akhlak serta sistem kerja sepanjang hari selama 24 jam. Oleh karena itu, penyelidikan kaidah-kaidah MSDM khsusnya pada sektor pengembangan sedikit banyak pasti akan mengalami penyesuaian saat dilaksanakan dilingkungan pondok pesantren.

\section{Bagan Kerangka Teori}

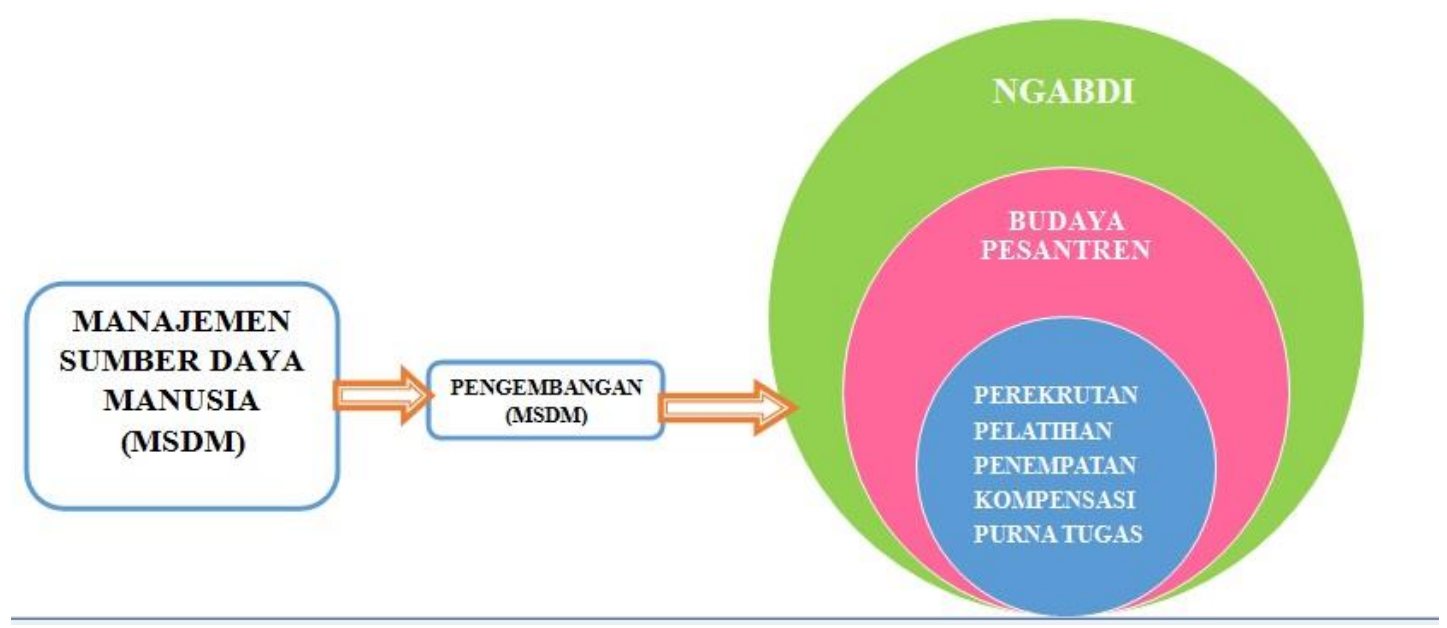

Mengabdi pada dasarnya adalah bekerja sukarela untuk membantu Kiyai atau pesantren. Sa'diyah (2015) menyatakan mengabdi pada dasarnya adalah melayani sepenuh hati tanpa mengahrapkan imbalan sesuai dengan kemampuan masing-masing. Mereka harus siap melaksanakan perintah apa saja asalkan tidak bertentangan dengan hukum dan aturan dalam Islam. Mengabdi tidak bisa diartikan hanya untuk mengajar tapi lebih dari itu harus mampu melayani tanpa mengharap balasan apapun, karena tujuan utamanya dalah untuk menharap ridho Allah SWT. Selain itu mengabdi juga merupakan bentuk ibadah. Sehingga, mereka harus mampu saling berintegrasi baik dengan lingkungan internal maupun eksternal.

Selanjutnya, mengabdi masih berkaitan dengan majanemen sumber daya manusia yang merupakan salah satu hal penting dalam menjalankan sebuah organisasi. Manajemen Sumber Daya Manusia merupakan ilmu dan seni yang

Pola Penerapan Sistem 'ngabdi'yang Dilakuka Pondok Pesantren Bahrul MaghfirohMalang dalam Konteks Manajemen Sumber Daya Manusia 
mengatur hubungan dan peranan tenaga kerja agar efektif dan efisien untuk membantu terwujudnya tujuan perusahaan, karyawan, dan masyarakat Hasibuan (2003). Kemudian menurut Umar (2005) manajemen sumber daya manusia adalah bagian dari manajemen keorganisasian yang memfokuskan diri pada unsur sumber daya manusia, yang bertugas mengelola unsur manusia secara baik agar diperoleh tenaga kerja yang puas akan pekerjannya. Selain itu, MSDM harus mempertimbangkan sisi pengambangannya. Sedarmayanti (2017) menyatakan pengembangan SDM merupakan langkah yang dilakukan untuk memperbaiki kapasitas produktifitas kinerja dari manusia.

Model struktur MSDM ada beberapa tahap. Pertama, Perekrutan merupakan hal yang perlu dilakukan pada tiap organisasi termasuk pondok pesantren. Sedarmayanti (2017) menjelaskan perekrutan atau penarikan adalah proses pencarian pegawai yang mampu dan bersedia untuk bekerja pada organisasi yang dituju. Sumbernya terbagi menjadi internal dan eksternal. Internal berasal dari dalam organisasi itu sendiri, sedangkan eksternal berasal dari luar organisasi. Pada pondok pesantren semua pengabdi mayoritas berasal dari internal. Sa' diyah (2015) mendeskripsikan pengabdian dilakukan atas timbal balik santri kepada Kyai atas ilmu yang telah diberikan selama belajar di pesantren (murid pada pondok pesantren). Oleh sebab itu, hal ini menjadi hal unik tersendiri dari sisi ngabdi.

Kedua, Pelatihan merupakan hal pokok yang harus dilakukan organisasi untuk memberikan bekal pada karyawannya sebelum bekerja. Pelatihan diperlukan untuk menjaga dan meningkatkan kualitas saat ini dan dimasa yang akan datang. Pelatihan harus mempertimbangkan kebutuhan, tujuan, program, bentuk, evaluasi, dan modifikasinya (Mukhibat, 2012). Kemudian, Haromain (2013) menjelaskan pelatihan dilakukan melalui pembagian tugas dan tanggung jawab tiap-tiap unit yang ada dalam pondok pesantren. Kemudian, Noe (2014) training harus mempertimbangkan konteks pelaksanaan, figur yang akan mengikuti training, dan materi seperti apa yang harus diberikan saat training. 
Ketiga, Penempatan berpotensi besar terhadap kinerja karyawan karena berpengaruh dengan motivasi dalam bekerja. Sebelum penempatan ada pengangkatan, pengangkatan umunya menggunakan sistem merit, yakni mengangkat karyawan berdasarkan kualitas, bakat, dan prestasi kerja (Sedarmayanti , 2017). Ruang lingkup pesantren biasanya didasarkan pada seberapa giat untuk mematuhi peraturan yang berlaku. Penempatan karyawan yang tepat akan membawa keuntungan pada organisasi. Sa'diyah (2015) mengungkapkan penempatan santri saat ngabdi berdasarkan perintah sang Kiyai, dan umumnya para santri akan mengikuti titah tersebut dengan ikhlas.

Keempat, Kompensasi merupakan bentuk apresisi organisasi pada karyawannya. Sedarmayanti (2017) menjelaskan kompensasi merupakan segala sesuatu yang di terima oleh pegawai sebagai wujud balas jasa atas kontribusinya. Desler (2013) mendeskripsikan kompensasi mempunyai dua bentuk. Pertama dalam bentuk pembayaran langsung seperti gaji, lembur, dan bonus. Kedua, dalam bentuk tidak langsung contohnya liburan dan asuransi yang didapatkan. Sa'diyah (2015) menjabarkan jika santri yang mengabdi tidak menerima upah, namun masih mendapatkan kompensasi dalam bentuk yang lain seperti ilmu yang bermanfaat dan keberkahan.

Terakhir, Suatu saat pasti ada pegawai yang berhenti bekerja dengan alasan tertentu. Sedarmayanti (2017) menjelaskan jika pemberhentian SDM disebabkan oleh permintaan sendiri, mencapai usia pensiun, penyederhanaan organisasi, tidak cakap jasmani rohani, dan meninggal dunia. Faktor-faktor tersebut harus sangat diperhatikan secara serius oleh organisasi, karena akan sangat berimbas jika tidak direncakan dengan maksimal. Terutama, pada organisasi yang baru berdiri harus memperhatikan keluar masukknya karyawan karena masih banyak mengalami trial and error. Berbeda dengan organisasi yang sudah berjalan lama karena mereka sudah memiliki sistem SDM yang sudah mumpuni.

\section{METODE PENELITIAN}

Penelitian ini mengaplikasikan kualitatif approach, karena studi yang dilakukan adalah penerapan sistem "ngabdi" pada Pondok Pesantren Bahrul 
Maghfiroh. Penelitian ini tergolong deskriptif karena memberikan penjabaran secara rinci tentang penerapan sistem "ngabdi" pada Pondok Pesantren Bahrul Maghfiroh.

Kiyai adalah informan utama dalam penelitian ini. Selain itu, beliau juga sebagai penentu kebijakan pesantren dan empat santri yang mengabdi dengan rincian satu santri yang purna pengabdian, dua santri yang mengabdi dua sampai lima tahun, dan satu santri yang mengabdi kurang dari satu tahun. Peneliti mengambil subjek berdasarkan tingkat penentu pengembangan MSDM dan pelaku atau pelaksana hal tersebut. Kiyai karena perannya yang sangat vital pada pondok pesantren (mengatur aturan sistem pengabdian). Kemudian santri yang mengabdi merupakan elemen penting dalam implementasi sistem tersebut. Peneliti sendiri menjadi instrumen pokok dalam penelitian ini, karena analisa bersifat deskriptif kualitatif. Selain itu juga digunakan instrumen seperti kamera dan telepon genggam sebagai alat pengambil data tambahan.

Penelitian ini mengaplikasikan teknik pengumpulan dengan beberapa prosedur. Wawancara tak terstruktur sebagai langkah awal yang dilakukan disini. Wawancara tak sterstruktur lebih fleksibel dalam meyampaikan pertanyaan untuk dilaksanakan dan mengikuti alur ketika berbicaara dengan responden berdasarkan Johnson (2008). Wawancara spontan juga diterapkan jika ada informasi penting yang akan digali dan terlewat dalam penggalian data. Recorder dalam telpon genggam adalah instrumen sekunder dalam penelitian ini. Wawancara disini direalisasikan dengan satu Kiyai dan empat santri yang telah ditentukan.

Kedua, observasi dilakukan dengan membuat catatan rinci dari apa-apa yang diamati di lapangan berdasarkan kebutuhan data penelitian. Peneliti termasuk participant as observer, khususnya peneliti satu dan tiga. Maksudnya menurut Johnson (2008) adalah subjek atau objek penelitian diberikan informasi jika sebagai sumber data, namun keterlibatan peneliti dalam objek tersebut juga aktif sebagai pelaku didalamnya. Darisitu, peneliti mendapatkan keuntungan untuk 
lebih leluasa dalam mengambil data dan unsur naturalistik data dapat terjaga. Ketiga, untuk memperkuat kebsahan dan kelengkapan data penelitian dilakukan dokumentasi. Hal ini untuk mempertajam analisa data yang dilakukan dan sebagai pendukung hasil penelitian.

Penelitian ini menganut beberapa langkah untuk teknik analisa datanya. Jika proses wawancara telah usai, transkripsi atau proses dari data audio menjadi data tertulis dilakukan. Kemudian dijadikan transkrip wawancara dengan hanya menulis data yang diperlukan saja dan mengeliminasi data yang tidak dibutuhkan. Lebih dari itu, kombinasi hasil transkrip, observasi dan dokumentasi dielaborasikan. Sehingga hasil yang didapatkan jauh lebih valid. Selanjutnya, data ditampilkan diintepretasikan berdasarkan teori yang telah ditulis dan dibandingkan dengan realita lapangan. Peneliti mengolah data dengan marwah sistem MSDM yang diterapkan Pondok Pesantren Bahrul Maghfiroh. Berdasarkan langkah-langkah tersebut didapatkan hasil dari penelitian dan dapat ditarik kesimpulan. Sebelum kesimpulan disajikan akan dilakukan triangulasi data untuk memastikan keabsahan hasil penelitian. Terakhir, dapat ditarik kesimpulan sebagai akhir dari penelitian.

\section{PEMBAHASAN}

Mengabdi ‘ngabdi 'pada pondok Pesantren Bahrul Maghfiroh mempunyai ciri khas dan keunikan tersendiri bila disandingkan dengan sistem yang serupa pada pesantren yang lain. Mengabdi disini mempunyai arti secara umum berjuang untuk kepentingan agama Islam dan sesama tanpa pamrih dengan kemampuan yang mereka miliki, khususnya di Bahrul Maghfiroh selain untuk memberikan pengalaman dan edukasi, mereka (santri) juga diajarkan untuk membantu tugas Guru (Pengasuh Pesantren) dalam hal pengelolaan mulai dari unit usaha, pendidikan, yayasan dan pesantren itu sendiri. Seperti ungkapan Ustadz Harun (Santri Senior) “Konsep mengabdi sebetulnya untuk mendidik atau edukasi. Ya itu tadi, mereka diajari berjuang untuk kelanjutan agama Islam. Sebetulnya ketika mengabdi itu mereka diajari untuk membantu guru mereka mengurus pondok pesantren yang didalamnya banyak sektor, seperti wirausaha, properti, pendidikan, 
dan lainnya". Secara detail, sistem mengabdi yang ada pada Pondok Pesantren Bahrul Maghfiroh dapat dijabarkan dan dibahas dalam beberepa tahapan.

Pertama, perekrutan atau santri yang diijinkan untuk mengabdi harus lulus jenjang pendidikan SMA (Sekolah Menegah Atas) yang ada di Ponpes Bahrul Maghfiroh dan berkeingainan untuk mengabdi, karena untuk melanjutkan di tempat lain juga diperbolehkan oleh pihak pesantren. Namun ada beberapa santri yang mengabdi sebelum lulus dari jenjang pendidikan SMA dan hanya mengaji saja. Santri yang berkomitmen untuk mengabdi akan diberikan perjanjian satu tahun untuk proses seleksi atau penyaringan apakah mereka layak untuk mengabdi lebih serius dalam jangka waktu lama. Kyai sekaligus Pengasuh Ponpes Bahrul Maghfiroh Prof. M. Bisri mengungkapkan "kami memberikan waktu satu tahun pada mereka yang ingin mengabdi sebagai proses screening sekaligus mengetahui minat dan bakat mereka lebih dalam untuk ditempatkan pada posisi yang tepat dalam unit usaha, pendidikan, atau sekolah"

Sumber daya manusia atau santri yang melakukan proses pengabdian diambil dari sisi internal. Sedarmayanti (2017) menjelaskan sumber internal berasal dari dalam organisasi itu sendiri. Alasan utama memilih dari sisi internal karena ingin mengembangkan output atau santri lulusan Bahrul Maghfiroh agar memiliki kompetensi yang mumpuni dan profesional dengan bidang keahlian yang diminati. Terlebih lagi mereka sudah paham tentang budaya dan kondisi pesantren dimana mereka tinggal. Unit usaha dalam Pondok Pesantren Bahrul Maghfiroh meliputi: BM Mart, Sultan Coffee, Budidaya Ikan Air Tawar, Budidaya Jamur, Sayuran Organik, Keju Mozarela, Yougurt, dan Budidaya Anggrek. Sedangkan pada unit pendidikan ada SMP, SMA, MTs dan Madrasah Diniyah Bahrul Maghfiroh. Kemudian, untuk yayasan ada berbagai sektor keuangan, sekretaris, administrasi, dan lainya.

Kedua, santri yang telah memilih jalan mengabdi dan memilih bidang fokus pengabdian akan mendapatkan pelatihan. Seperti yang diungkapkan Mustaqim (santri pengabdian) "santri yang mengabdi di tahun pertama akan medapatkan pelatihan dari paktisi untuk menunjang kompetensi yang dimiliki". Pelatihan disini kebanyakan dilakukan sembari praktek kerja atau on the job training. Selain itu, 
pelatihan lain dan workshop juga diberikan pada santri yang mengabdi lebih dari satu tahun untuk mengikuti perkembangan pengetahuan dan tren bisnis dari bidang-bidang pengabdian yang mereka geluti. Mukhibat (2012), Haromain (2013), Noe (2014) mendeskripsikan jika training harus diberikan sesuai program dan tujuan kerja yang sebenarnya, agar mereka siap dan cekatan saat bekerja. Hal ini menjadi faktor yang unik dalam pengabdian yang ada di Bahrul Maghfiroh, dengan diadakannya training, karena jika pengabdi di pondok hanya mendapat sedikit pelatihan dari bidang yang mereka geluti saat pengabdian yang mengakibatkan lamanya adaptasi pada pekerjaannya.

Ketiga, penempatan santri yang mengabdi pada pondok pesantren ini didasarkan pada passion atau minat mereka ingin mengabdi disektor yang mereka pilih. Walapun demikian peran pengurus pondok dan pengasuh juga vital untuk memberikan saran sektor apa untuk santri pengabdian tersebut. Mihwan (pengurus ponpes dan yayasan) menyatakan "penempatan kita sesuaikan dengan mau mereka dimana, kemudian kita cocokkan dan berikan saran sesuai dengan bakat mereka" Selanjutanya Prof. Bisri (pengasuh ponpes) menjelaskan "kita tetap pantau mereka cocoknya dimana, seperti mustaqim ini cocoknya jadi sekretaris, ya diberikan tugas itu". Sehingga, dalam satu tahun, jika mereka menunjukkan tren yang positif maka akan diangkat menjadi pengurus (pengabdian total ke pesantren), namun jika mereka lebih tertarik untuk melanjutkan perjalanan mereka diluar pondok pesantren juga diijinkan. Minimal mereka sudah mendapatkan pengalaman mengabdi dan bekerja selama satu tahun untuk bekal mereka diluar.

Hal tersebut sesuai dengan (Sedarmayanti, 2017) yang menyatakan penempatan karyawan (santri) didasarkan pada merit sistem. Tetapi, fakta tersebut kurang sesuai dengan Sa'diyah (2015) yang mengungkapkan penempatan santri saat ngabdi berdasarkan perintah sang Kiyai dan umumnya para santri akan mengikuti titah tersebut dengan ikhlas. Pada pondok pesantren Bahrul Maghfiroh apapun keputusan Kiyai memang akan diikuti oleh para santri dengan sepenuh hati, namun keputusan Kiyai didasarkan pada screening satu tahun dan masukan dari para pengurus pesantren yang mengasuh santri sejak awal mereka masuk dipesantren. 
Keempat, kompensasi menjadi salah satu hal pokok dalam konteks MSDM. Pada Pondok Pesantren Bahrul Maghfiroh, kompensasi sangat diperhatikan untuk menunjang kesejahteraan santri yang melakukan pengabdian. Kompensasi yang diberikan untuk santri pengabdian disini disarkan pada beban kerja yang mereka tempuh. Secara umum patokan untuk kompensasi langsung didasarkan pada upah minimum Kota Malang sekitar dua jutaan. Namun jika beban kerja melebihi dari 8 jam dan unit usaha berkembang pesat, maka kompensasi langsung bias melebihi upah minimum. Prof. Bisri menjelaskan "kami berusaha terus untuk meningkatkan kompensasi bagi mereka (santri pengabdian) sesuai dengan standar, tapi jika unit usaha berkembang pesat, kompensasi yang mereka dapat juga akan lebih besar. Itu, contohnya manajer keju mozarela satu bulan bisa mencapai 10 juta gajinya.Untuk karyawan sudah bisa sesuai upah minimum bahkan bisa lebih". Untuk kompensasi tidak langsung mereka kebanyakan mengharapkan keberkahan dari Kiyai. Lebih dari itu, mereka mendapatkan akses untuk membuka networking agar mereka mampu memperluas komunitas profesionalitas mereka. Selanjutnya, mereka juga banyak mendapatkan pelatihan untuk menunjang keahlian mereka.

Struktur kompensasi pada Bahrul Maghfiroh sedikit berbeda dengan ponpes pada umumnya. Sa' diyah (2015) menyatakan jika santri tidak menerima upah saat pengabdian. Umunya santri mengabdi memang tanpa kompensasi langsung, tapi Bahrul Maghfiroh memberikan itu untuk wujud apresiasi, kesejahteraan, sekaligus memberikan semangat bagi mereka. Meskipun demikian ada tidaknya kompensasi tidak mengurangi semangat para santri untuk mengabdi pada pesantren mereka.

Terakhir, untuk proses santri yang mengabdi kemudian berhentian kerja (ngabdi) di Pondok Pesantren Bahrul maghfiroh berdasarkan penelitian hanya berdasarkan kemauan santri sendiri untuk memilih boyong (mundur berhenti mengabdi). Menurut hasil observasi mereka yang menyatakan berhenti mengabdi memilih untuk melanjutkan karir profesionalnya di luar pesantren atau membuka usaha sendiri. Hal tersebut sesuai dengan Sedarmayanti (2017) menjelaskan jika pemberhentian SDM disebabkan oleh permintaan sendiri, mencapai usia pensiun, 
penyederhanaan organisasi, tidak cakap jasmani rohani, dan meninggal dunia.

Proses ini merupakan sesuatu yang belum banyak diolah pada ranah MSDM di Bahrul Maghfiroh. Harapanya kedepan ada sebuah formulasi khusus yang menjabarkan tentang sistematika pemberhentian santri yang mengabdi. Sehingga kualitas SDM Bahrul Maghfiroh semakin berkualitas.

\section{KESIMPULAN}

Berdasarkan pembahasan pada penelitian ini maka dapat ditarik kesimpulan sebagai berikut:

1. Santri yang mengabdi minimal harus lulus SMA atau program paket $\mathrm{C}$

2. Pelatihan dilakukan dengan menghadirkan praktisi dan bersifat on the job training

3. Penempatan kerja dilakukan berdasarkan bakat, kemampuan, dan kemauan santri serta rekomendasi dari pengurus pondok

4. Kompensasi diberikan untuk memberikan semangat dan kesejahteraan bagi santri yang mengabdi

5. Santri yang berhenti mengabdi mayoritas berdasarkan kemauan mereka sendiri ketika ingin berkarir diluar untuk lebih profesional

\section{DAFTAR PUSTAKA}

Atsniah, lia \& Ratna Supradewi (2019) Makna Hidup Santri Pengabdian Pondok Pesantren Nurul Aman. Konferensi Ilmiah Mahasiswa Unissula 2. Prosiding 361-366.

Dessler,Gary. 2013. Human Resource Management. New Jersey: Pearson.

Elaine Farndale \& Karin Sanders (2017) Conceptualizing HRM system strength through a cross-cultural lens, The International Journal of Human Resource Management, 28:1, 132-148, DOI: 10.1080/09585192.2016.1239124.

Fahrurrozi (2015) Budaya Pesantren di Pulau Seribu Masjid, Lombok. Jurnal Sosial dan Kebudayaan Islam, Vol. 3, No. 2, 324-345.

Haromain (2013) Manajemen Pengembangan SDM Pondok Pesantren.Jurnal Pendidikan Humaniora. Vol. 1, No. 2, 136-149.

Hasibuan, Malayu S.P.2002. Manajemen Sumber Daya Manusia Jakarta: Bumi Aksara.

Johnson, Burke \& Christensen, Larry. 2008. Educational Research Quantitative, Qualitative, Mixed Approaches. California: Sage Publications.

Pola Penerapan Sistem 'ngabdi'yang Dilakuka Pondok Pesantren Bahrul MaghfirohMalang dalam Konteks Manajemen Sumber 
Mukhibat (2012) Manajemen SDM dalam Pondok Pesantren.Forum Tarbiyah.Vol. 10, No.2, 174-185.

Noe, Raymond A. 2014. Funddamental of Human Resource Management, Sixth Edition. New York: McGraw-Hill Education.

Sa'diyah, Cholilatus. 2015. Pemaknaan Barakah dalam Pengabdian Santri di Pondok Pesantren Nurul Huda Dusun Suci Desa Jubellor Kecamatan Sugio Kabupaten Lamongan.Skripsi. digilib.uinsby.ac.id

Sedarmayanti. 2017. Perencanaan dan Pengembangan SDM untuk Meningkat Kompetensi, Kinerja, dan Produktivitas Kerja. Bandung: PT. Refika Aditama

Umar, Husein. 2005. Riset SDM Dalam Organisasi. Jakarta: PT SUN 